\title{
Sobre concordância verbal, aprendizagem da escrita e gramáticas múltiplas
}

Stefania ZANDOMÊNICO ${ }^{1}$

Eloisa PILATI ${ }^{2}$

\footnotetext{
${ }^{1}$ Secretaria de Educação do Distrito Federal (SEDF), stefania.rezende@gmail.com, orcid. org/000०-0002-5189-8581.

${ }^{2}$ Universidade de Brasília (UnB), eloisapilati@gmail.com, orcid.org/oooo-ooo3-2895-5557.
} 
RESUMO O presente artigo investiga os efeitos do processo de escolarização no uso da concordância verbal por falantes que passaram pelo processo de letramento durante a Educação Básica. O objetivo é duplo: por um lado, pretende-se compreender os padrões de concordância verbal usados por falantes letrados e, por outro, deseja-se discutir a adequação das propostas de Roeper (1999) e Kato (2005) ao fenômeno estudado. A metodologia utilizada foi a análise variacionista dos padrões de concordância verbal usados em textos escritos por alunos oriundos da EJA e do ensino regular, recolhidos em provas do ENEM (ZANDOMÊNICO 2018), e a posterior comparação entre os resultados obtidos com os resultados de estudos variacionistas anteriores (NARO 1981; SCHERRE \& NARO 1998; VIEIRA 2011; GRACIOSA 1991; BERLINCK et al., 2009). Os resultados da análise levam à conclusão de que, em relação à concordância verbal, a hipótese mais adequada para dar conta do fenômeno estudado - a concordância verbal na gramática do letrado - é a das gramáticas múltiplas, de Roeper (1999), em que se defende que todos os falantes possuem um conjunto de minigramáticas para serem usadas em diferentes domínios. Isso porque os padrões de concordância verbal apresentados nos textos escritos analisados se mostraram sujeitos às mesmas variáveis da gramática da 
fala, com diferenças apenas em relação aos pesos das variáveis. A hipótese da "gramática do letrado" de Kato (2005) foi considerada problemática no que se refere ao fenômeno da concordância verbal. A autora sugere que a aquisição de uma segunda língua e a aquisição da escrita são processos semelhantes, que ocorrem por meio da gramática da L1. Para a autora, os falantes "bilíngues" apresentam a gramática da L1 em sua gramática nuclear e a gramática da L2, ou a da escrita no caso dos falantes letrados, na periferia marcada. Nos falantes letrados, a periferia marcada da Língua-I seria maior do que a dos falantes não letrados, e haveria alternância de código (codeswitching) entre a G1 (gramática nuclear) e a G2 (periferia marcada); por esse motivo, a G2 apresentaria "fragmentos superficiais de uma gramática constituída pela fixação de parâmetros" (KATO, 2005, p. 9). No caso da concordância verbal, a gramática da escrita mostrou propriedades bastante similares às da gramática da fala, portanto a hipótese de uma gramática fragmentada não se mostra adequada.

ABSTRACT This paper investigates the effects of the schooling process in the use of verbal agreement by speakers who have gone through the literacy process in Basic Education. Our objective is twofold: on one 
hand, we want to understand the patterns of verbal agreement used by literate speakers, on the other hand, we want to discuss the adequacy of previous proposals to describe the phenomena under study (ROEPER 1999; KATO 2005). The methodology used in this study is the variationist analysis of verbal agreement patterns found in written texts by students from both EJA (Brazilian Education of Youth \& Adults) and regular education. The written material was gathered from ENEM's examination (Brazilian High School National Exam) (ZANDOMÊNICO 2018). Subsequently, a comparison was established between these results and previous ones, from variationist studies (NARO 1981; SCHERRE \& NARO 1998; VIEIRA 2011; GRACIOSA 1991; BERLINCK et al., 2009). The results from the analysis lead to the conclusion that, with respect toverbal agreement, the most adequate hypothesis to deal with the phenomena under study is the multiple grammars hypothesis, by Roeper (1999). According to this hypothesis, every speaker has a set of mini-grammars that can be used in different domains. This is the case because the patterns of verbal agreement found in the analyzed written texts were shown to be subject to the same variables as the grammar of the spoken language. The differences relate to the weight of these variables. The hypothesis of "the grammar of literate people" (KATO 2005) was considered 
problematic with respect to the phenomena of verbal agreement. The author suggests that the acquisition of a second language and the acquisition of writing are similar processes, mediated by the grammar of the first language. According to her, "bilingual" speakers have the grammar of their first language in their nuclear grammarand the grammar of a second language (or the grammar of the written language, in the case of literate individuals) in the marked periphery. Regarding literate individuals, the marked periphery of the I-Language would be larger if compared to illiterate individuals, with an alternation between the G1 (nuclear grammar) and the G2 (marked periphery). For this reason, the G2 would exhibit "superficial fragments of a grammar constituted by the process of fixing parameters" (KATO, 2005, p. 9). With respect to verbal agreement, both the grammar of the written language and spoken language showed very similar properties. Therefore, the hypothesis of a fragmented grammar is deemed inadequate.

PALAVRAS-CHAVE concordância verbal. escrita. aprendizagem. gramáticas múltiplas. gramática do letrado.

KEYWORDS verbal agreement. writing. learning. multiple grammars. the grammar of literate speakers. 


\section{Introdução}

Os estudos gerativistas, fundados por Noam Chomsky, desde o final da década de 50, têm, entre seus objetivos principais, investigar as propriedades da Faculdade da Linguagem, que consiste na capacidade inata dos seres humanos para desenvolver uma língua de forma natural, e da gramática internalizada pelos falantes, o que se denomina na literatura especializada como Língua-I. Inúmeros pesquisadores têm se dedicado a investigar as propriedades que fazem parte da Língua-I dos falantes e que podem ser classificadas sinteticamente em Princípios Universais - que regem a forma das línguas humanas - e Parâmetros - que são as especificidades dos sistemas linguísticos das diferentes línguas. A fim de investigar as propriedades das línguas naturais, os estudos gerativistas usam como principal fonte de dados as intuições dos falantes e os dados naturais de fala.

Ao mesmo tempo em que a Teoria Gerativa tem se dedicado a investigar as questões relacionadas aos conhecimentos inatos dos falantes e às propriedades da Faculdade da Linguagem, outras questões e hipóteses relativas aos usos linguísticos, em diferentes contextos, também vieramà tona, tais como o questionamentoacerca das etapas da aquisição linguística, questões relativas ao bilinguismo, ao multiliguismo e ao processamento linguístico e questões sobre a influência dos processos de escolarização na Língua-I dos falantes.

O presente artigo se dedica precisamente a analisar este último tema. Investigaremos, portanto, as influências dos processos de escolarização no saber gramatical de estudantes brasileiros. Para abordarmos o tema de maneira concreta, selecionamos o fenômeno de concordância verbal presente em textos escritos de estudantes brasileiros letrados. A metodologia utilizada foi a análise variacionista dos padrões de concordância verbal de textos escritos por alunos oriundos da EJA e do ensino regular, recolhidos em provas do ENEM (ZANDOMÊNICO 2018), e a posterior comparação entre 
os resultados obtidos com os resultados de estudos variacionistas anteriores (NARO 1981; SCHERRE \& NARO 1998; VIEIRA 2011; GRACIOSA 1991; BERLINCK et al., 2009).

O presente artigo se organiza da seguinte forma: na primeira seção, apresentamos um panorama resumido de estudos variacionistas sobre a concordância na fala (NARO 1981; GRACIOSA 1991; SCHERRE \& NARO 1998; BERLINCK et al., 2009; VIEIRA 2011) e na escrita (SCHERRE \& NARO 1998; SCHERRE 2005) do Português Brasileiro, comparando-os com os dados de concordância verbal produzidos por alunos concluintes do Ensino Médio provenientes da EJA e do ensino regular (ZANDOMÊNICO 2018), extraídos de redações do ENEM 2013. Em seguida, apresentamos duas propostas teóricas acerca da aquisição de uma segunda gramática - Roeper (1999) e Kato $(2005)^{1}$ - e discutimos as referidas propostas teóricas no que diz respeito ao processo de aquisição da escrita, especificamente frente aos padrões de concordância verbal encontrados nos textos escritos de alunos oriundos da EJA analisados em Zandomênico (2018). Por fim, trazemos as considerações finais.

\section{Estudos sobre concordância verbal na fala e na escrita}

Veremos, nesta seção, o que estudos variacionistas revelaram sobre a concordância verbal na fala e na escrita. Em seguida, apresentaremos o que os dados escritos de Zandomênico (2018) revelaram sobre a concordância verbal na escrita de alunos da EJA e do ensino regular concluintes do Ensino Médio. A apresentação dos estudos variacionistas sobre a fala e a posterior comparação com os estudos sobre a escrita de Zandomênico (2018) será fundamental para a argumentação que se pretende desenvolver nesse artigo, que é a seguinte: no que se refere ao fenômeno da concordância verbal, os

${ }^{1} \mathrm{Na}$ literatura, existem outras linhas de investigação, tais como a de Kenedy (2016), que consideram que as propostas de Roeper (1999) e Kato (2005) são propostas conciliáveis. Neste artigo, defenderemos que há diferenças relevantes entre as duas propostas. 
dados revelam que a gramática da escrita desses falantes é regida por variáveis muito semelhantes às da fala, o que, para nós, mostra que o fenômeno estudado não constitui uma gramática fragmentada, e sim um sistema perfeito e regular que se adequa às especificidades da escrita. ${ }^{2}$

\subsection{Estudos variacionistas sobre a concordância verbal na fala (NARO 1981; SCHERRE \& NARO 1998; VIEIRA 2011, GRACIOSA 1991; BERLINCK et al., 2009)}

\subsubsection{Naro (1981)}

Os trabalhos desenvolvidos por Naro e Lemle na década de 1970, e, em especial, o trabalho desenvolvido por Naro no início da década seguinte (1981) deram início ao estudo sistemático sobre a concordância no Brasil. Os estudos revelaram que a concordância verbal não consiste em fenômeno categórico e que a ausência de marcas de concordância não é exclusiva da fala dos não escolarizados; está associada, inclusive, a fatores sociais, tais como sexo e idade.

Naro (1981) apresenta um estudo quantitativo detalhado de uma mudança sintática em processo - a perda da concordância de terceira pessoa entre sujeito/verbo no Português Brasileiro moderno - e sugere, com base nesta e em outra evidência, uma hipótese geral

\footnotetext{
${ }^{2}$ As amostras utilizadas em Zandomênico (2018), que compreendiam dados de alunos provenientes da EJA e dados de alunos provenientes do ensino regular, foram analisadas de duas formas. Primeiramente, elas foram comparadas entre si - EJA vs. ensino regular. Posteriormente, com os resultados de alguns estudos variacionistas sobre a concordância verbal na fala, que analisavam as variáveis linguísticas e sociais aqui mencionadas em dados de falantes de diferentes níveis de escolaridade (NARO 1981; SCHERRE \& NARO 1998; VIEIRA 2011; GRACIOSA 1991; BERLINCK et al., 2009; SCHERRE, CARDOSO \& NARO 2007) - escrita vs. fala. A análise levou em consideração, ainda, alguns poucos estudos variacionistas que tratavam da concordância verbal na escrita, nos quais se analisavam especialmente as construções com sujeito complexo em dados de falantes escolarizados (SCHERRE \& NARO 1998; SCHERRE 2005). Neste artigo, apresentamos parte do trabalho da autora, especificamente, a comparação feita entre os resultados da pesquisa variacionaista de Zandomênico (2018) e os resultados dos estudos variacionistas mencionados.
} 
sobre a mudança sintática. Para tanto, o autor emprega uma série de variantes, de ordem linguística e social, em sua análise.

Segundo Naro (1981, p. 66), a concordância entre sujeito e verbo é quase categórica nos falantes escolarizados. A única circunstância em que ocorre variação em larga escala neste grupo é quando o sujeito é posposto ao verbo. Por essa razão, seu estudo limitou-se à fala de pessoas com níveis socioeconômicos mais baixos.

Naro afirma que a falta de concordância é mais saliente quando o sujeito plural ocorre imediatamente posposto ao verbo correspondente do que quando ele é separado doverbo por elementos intervenientes (advérbios, orações relativas etc.), que separam física e temporalmente o verbo plural dependente do sujeito plural determinante. Quando o sujeito segue o verbo, a ausência de marcas de concordância é ainda menos saliente (NARO, 1981, p. 68).

Arelaçãoposicionalémaissalientequandoosujeitodeterminante precede imediatamente o verbo determinado (NARO, 1981, p. 79). Os resultados do estudo revelam que a classe que consiste de sujeitos imediatamente antes do verbo mostra a maior taxa de concordância, seguida pela classe em que o sujeito ainda é realizado e anteposto, mas separado do verbo por alguma distância. A mais baixa taxa de concordância da hierarquia é motivada pelo sujeito pós-verbal.

A variável idade mostra uma taxa significativamente mais alta de concordância para o grupo mais velho. Com relação ao sexo, as mulheres se aproximam mais da forma de prestígio do que os homens, ainda que a diferença seja muito pequena e represente apenas uma proporção mínima de toda a variação. O local de origem dos falantes não mostrou efeito significativo (NARO, 1981, p. 86).

Passemos, agora, às contribuições dos trabalhos que se seguiram ao de Naro (1981). 


\subsubsection{Scherre \& Naro (1998), Vieira (2011), Graciosa (1991), Berlinck et al. (2009)}

Depois de Naro (1981), uma série de trabalhos sobre a concordância verbalnafalasedesenvolveunoBrasil.Todosseguiramospressupostos apontados por Naro, e, posteriormente, os pressupostos apontados por Scherre \& Naro. Apresentaremos, aqui, alguns desses trabalhos - Scherre \& Naro (1998), Vieira (2011), Graciosa (1991) e Berlinck et al. (2009) -, dada a sua relevância para a presente pesquisa. A ordem de apresentação dos trabalhos, de maneira geral, está relacionada ao nível de escolaridade dos falantes - iniciando pelas pesquisas que investigam a fala de analfabetos e encerrando com as pesquisas que investigam a fala de indivíduos com muitos anos de escolaridade. A exceção fica por conta de Scherre \& Naro (1998), uma vez que este trabalho envolve falantes de diferentes níveis de escolaridade.

O trabalho de Scherre \& Naro (1998, p. 1-2) tem o objetivo de mostrar que os processos variáveis de concordância de número do português vernacular do Brasil evidenciam um sistema perfeito, no qual existe uma variação inerente altamente estruturada em função de aspectos linguísticos e sociais, de forma que é possível prever em que estruturas linguísticas e em que situações sociais os falantes são mais propensos a empregar todas as marcas formais de plural nos elementos flexionáveis das diversas construções (SCHERRE \& NARO, 1998, p. 13) $)^{3}$.

\footnotetext{
${ }^{3}$ No original: “os processos variáveis de concordância de número do português vernacular do Brasil evidenciam um sistema perfeito, correlacionado a variáveis linguísticas e sociais" (SCHERRE \& NARO, 1998, p. 1-2); "verifica-se que a variação na concordância no português falado do Brasil está definitivamente internalizada na mente de seus falantes. Neste momento da língua, trata-se de uma variação inerente, altamente estruturada em função de aspectos linguísticos e sociais. Pelos resultados obtidos, evidencia-se que existe um sistema gerenciando a variação na concordância de número no português do Brasil, sendo, portanto, possível se prever em que estruturas linguisticas e em que situações sociais os falantes são mais propensos a colocar ou não todas as marcas formais de plural nos elementos flexionáveis das diversas construções. Pelo menos em termos de escrita, verifica-se que a variação não é específica do português do Brasil, podendo ser encontrada no português escrito de Portugal exatamente nos mesmos contextos do português do Brasil e, também, do português arcaico" (op. cit.:13-14).
} 
Vejamos os exemplos apresentados pelos autores para ilustrar essa situação de variação sistemática:

(1)

a. concordância verbo/sujeito:

- ... eles GANHAM demais da conta (variante explícita);

- .. eles GANHA0 demais (variante zero).

b. concordância entre os elementos do sintagma nominal

- oS freguesES; aS boaS açÕES; essaS coisaS todaS (variantes explícitas);

- essaS estradaS nova0; do0 meuS paiS (variantes explícitas e variantes zero);

- aS codorna0; aS porta0 aberta0 (variantes explícitas e variantes zero).

c. concordância nos predicativos e particípios passivos

- ... as coisas tão muito CARAS, né? ... (variante explícita);

- ... que as coisao táo CARA0, num dá mesmo ... (variante zero);

- ... os meus filhos foram AMAMENTADOS ... (variante explícita);

- ... os meus filhos foram ALFABETIZADO0 ... (variante zero).

Discutem-se, primeiramente, resultados da concordância de número nos fenômenos mencionados acima, com foco nas variáveis linguísticas saliência fônica e posição. A seguir, é analisada a influência de três variáveis sociais convencionais: anos de escolarização, sexo e faixa etária. Por fim, embora a escrita não constitua o foco do trabalho, apresentam-se algumas considerações sobre a variação da concordância de número na escrita padrão. 
$\mathrm{Na}$ análise da variável saliência fônica, os autores retomam os resultados de pesquisas anteriores feitas com amostras de fala de falantes analfabetos, segundo os quais o aumento da saliência do material fônico na oposição singular/plural dos verbos analisados aumenta as chances concordância verbal, ou da variante explícita de plural (cf. NARO \& LEMLE 1976; LEMLE \& NARO 1977; NARO 1981; apud SCHERRE \& NARO, 1998, p. 4). Os dados analisados são separados em seis grupos, de acordo com a hierarquia da saliência fônica estabelecida, nos moldes propostos por Naro (1981).

Observa-se que os resultados dos dois estudos (NARO, 1981; SCHERRE \& NARO, 1998) são bastante semelhantes, embora os dados sejam produzidos por falantes de diferentes idades e níveis de escolaridade: os dados de Naro (1981) se referem a dados de analfabetos; os dados de Scherre \& Naro (1998), a falantes com 1 a 11 anos de escolarização. Em ambos os casos, os níveis mais baixos da hierarquia de saliência, isto é, os níveis em que a oposição fônica entre as formas singular e plural é menos nítida, não acentuada (1a, $1 \mathrm{~b}$ e 1c), favorecem menos a concordância do que os níveis mais altos, isto é, os níveis em que a oposição fônica entre as formas singular e plural é mais nitida, acentuada (2a, 2b e $2 \mathrm{c}$ ).

Vejamos, em (2) e (3) a seguir, a que se refere cada um desses níveis da hierarquia:

(2)

Nível 1 (oposição não acentuada): "contém os pares nos quais os segmentos fonéticos que estabelecem a oposição são NÃO ACENTUADOS em ambos os membros" (NARO, 1981, p. 74) 
1a: não envolve mudança na qualidade da vogal na forma plural

- Eles conhece0 Roma. Conhece Paris (MOR45MC51/2470)

- Ceys conheceM? (NAD36FG57/1119)

1b: envolve mudança na qualidade da vogal na forma plural

- Eles ganha0 demais po que eles fayz (CABo2MP16/0026)

- Eles ganhaM demais da conta (CABo2MP16/0012)

1c: envolve acréscimo de segmentos na forma plural

- Eles também não diz0 (LAU28FC43/2601)

- Eles dizEM: “chutei tudo” (HEL34FG62/1887)”

(3)

Nível 2 (oposição acentuada): “o segundo nível contém aqueles pares nos quais [os segmentos fonéticos que estabelecem a oposição] são ACENTUADOS em pelo menos um membro da oposição" (NARO, 1981, p. 74)

2a: envolve apenas mudança na qualidade da vogal na forma plural

- Os filho tá0 pedindo dinhero (LEIo4FP25/0055)

- Eles tÃO bem intencionados (JOS35FP59/0962)

2b: envolve acréscimo de segmentos sem mudanças vocálicas na forma plural; inclui o parfoi/foram que perde a semivogal

- Aí bateu0 dois senhores na porta (NIL12FP45/0646)

- (eles) bateRU sete chapa da cabeça dele (LEI04FP25/OO84) 
2c: envolve acréscimos de segmentos e mudanças diversas na forma plural: mudanças vocálicas na desinência, mudanças na raiz, e até mudanças completas.

- Aí, veio0 aqueles cara correno atrás de (ALE55MG13/0555)

- vIERAM os ladrões, quatro, hum? (ARI3OFG43/1665)

- Agora, os vizinho daqui é0 ótimo (EDP13MP62/0758)

- Mesmoaqueles queSÃO sinceros(EDBo7MP41/O334)

(SCHERRE \& NARO, 1998, p.3-4)

Com base nos resultados obtidos, os autores ressaltam dois aspectos: (i) a regularidade absoluta no efeito da saliência fônica na sua primeira dimensão (oposição não acentuada, desfavorecendo a concordância, vs. oposição acentuada, favorecendo a concordância, independentemente dos anos de escolarização do falante) e (ii) a separação nítida entre a primeira categoria da oposição não acentuada e as outras duas categorias, em todos os grupos de falantes analisados.

Os autores constataram, ainda, que, em termos escalares, para a concordância verbal, a escala da saliência é mais nítida nos dados dos falantes com menos anos de escolarização, como se vê nos resultados que Naro (1981) apresenta para os falantes analfabetos e nos que Scherre \& Naro (1998) apresentam para os falantes que têm de 1 a 4 anos e de 5 a 8 de escolarização ${ }^{4}$. Em outras palavras, os autores verificaram que, quanto menos anos de escolarização,

\footnotetext{
${ }^{4} \mathrm{~A}$ frequência de marcas de concordância entre os falantes analfabetos analisados em Naro (1981) inicia-se, no nível 1a, com 15\%, e cresce gradativamente até chegar a 80\%, no nível 2c. Entre os falantes com escolaridade de 1 a 11 anos, a frequência de marcas de concordância inicia-se, no nível 1a, com 44\%, e cresce gradativamente até chegar a $88 \%$, no nível $2 \mathrm{c}$. A nitidez na escala de saliência, portanto, é maior entre os falantes com menos escolarização, visto que a diferença entre o nível mais baixo (de oposição menos acentuada) e o nível mais alto (de oposição mais acentuada) na escala de saliência - isto é, a diferença percentual entre os níveis 1a e 2c-é maior entre os falantes menos escolarizados.
} 
maior é a nitidez na escala de saliência dos falantes. Por essa razão, os pesquisadores pressupõem que a nitidez da escala da saliência na concordância verbal tem a ver com as diferenças entre os anos de escolarização dos falantes.

O trabalho, conforme já mencionado, também envolve a análise da variável posição do sujeito, visto que pesquisadores diversos (cf., por exemplo, LEMLE \& NARO, 1977; NARO, 1981, apud SCHERRE \& NARO, 1998, p. 8) têm demonstrado que a presença do sujeito e a sua posição em relação ao verbo têm forte influência no tipo de variante nas formas verbais. Os quatro fatores focalizados no trabalho, mais uma vez, seguem a mesma linha do proposto por Naro (1981).

Vejamos os exemplos apresentados pelos autores para os quatro fatores da variável posição do sujeito:

(4)

a. sujeito imediatamente anteposto:

- Eles dizEM: "chutei tudo" (HEL34FG62/1887);

b. sujeito anteposto separado do verbo por 1 a 4 sílabas:

- Eles também não diz0 (LAU28FC43/2601);

c. sujeito anteposto separado do verbo por 5 ou mais sílabas:

- Essas troca de experiência vai0 crescendo (PAC2OMG25/0169);

d. sujeito posposto ao verbo:

- Aí bateu0 dois senhores na porta (NIL12FP45/0646).

Os resultados da pesquisa, corroborando o de pesquisas anteriores, indicam que sujeito anteposto ao verbo ou imediatamente a ele mais próximo favorece a variante explícita, e que sujeito anteposto distante ou posposto ao verbo a desfavorece (SCHERRE \& NARO, 1998, p. 8). Este efeito é sempre uniforme e independe do grau de escolarização dos falantes. 
Com relação às variáveis sociais, o estudo analisou três variáveis sociais convencionais: sexo, anos de escolarização e faixa etária. As variáveis consideradas como mais significativas foram os anos de escolarização e o sexo. Os resultados destas variáveis indicaram que os fenômenos analisados são sensíveis a variáveis sociais, o que, segundo os autores, revela as pressões que os falantes sofrem pelo fato de a variante zero ser estigmatizada pelos padrões gramaticais vigentes. As pessoas com mais anos de escolarização (por estarem mais expostas à correção gramatical) e as do sexo feminino (por infringirem menos as regras sociais estabelecidas, como pesquisas já atestam - sendo, portanto, mais sensíveis às normas de prestígio) apresentaram mais a variante explícita de plural.

A conclusão do trabalho é de que a variação na concordância no português falado do Brasil está internalizada na mente de seus falantes. Trata-se de uma variação inerente, sendo altamente estruturada em função de aspectos linguísticos e sociais. E, uma vez que existe um sistema gerenciando a variação na concordância de número no português do Brasil, é possível prever em que estruturas linguísticas e em que situações sociais os falantes são mais propensos a empregar todas as marcas formais de plural nos elementos flexionáveis das diversas construções (SCHERRE \& NARO 1998,p.13).

Ainda sobre a variação da concordância verbal na fala, Vieira (2011) contrastou os dados produzidos por falantes analfabetos ou semianalfabetos com os dados produzidos por falantes com curso superior completo (GRACIOSA 1991 apud VIEIRA 2011, p. 87) e constatou nítido contraste na realização da regra consoante o grau de escolaridade do indivíduo. Graciosa registrou $89 \%$ de marcas de concordância e $11 \%$ de não concordância verbal nos dados de fala ao analisar a variedade culta ${ }^{5}$ falada por indivíduos do Rio de Janeiro

\footnotetext{
${ }^{5}$ Neste trabalho, empregamos a expressão "fala culta" tão somente com o sentido de "fala de indivíduos escolarizados", e unicamente quando nos referimos a autores que usam essa expressão.
} 
com nível superior completo. Retomaremos o trabalho de Graciosa (1991) mais adiante, nesta mesma seção.

Vieira (1995) constatou que a ausência da marca de número em verbos de $3^{\text {a }}$ pessoa, nafala defalantes analfabetos ou semianalfabetos decomunidades donortedoestadodoRiodeJaneiro,eracondicionada mormente por fatores de ordem estrutural. Desses fatores, foram significativos a saliência fônica, o paralelismo (nos níveis oracional e discursivo) e a posição do sujeito em relação ao verbo.

No que diz respeito à saliência fônica, a pesquisa de Vieira (1995 apud VIEIRA, 2011, p. 89) constatou que, quanto menor a diferença material fônica entre as formas singular e plural dos verbos, maior a ausência de concordância, confirmando o que Scherre \& Naro (1998) já haviam constatado. Logo, há mais casos de não concordância em verbos como comem e falam, por exemplo - cujas formas singulares correspondem a come e fala, respectivamente -, do que em formas como são e vieram - cujas formas singulares correspondem a é e veio, respectivamente.

Quanto ao paralelismo, Vieira confirmou "a pertinência do princípio do paralelismo nos níveis oracional e discursivo, o qual postula que marcas levam a marcas e zeros levam a zeros" (VIEIRA, 2011, p. 89). No nível oracional, a autora constatou que o menor número de marcas formais no sintagma nominal sujeito leva à ausência de marcas formais de concordância no sintagma verbal, como se verifica, por exemplo, em $(5)^{6}$. Também se verificou o contrário: quando há marcas formais de concordância no sintagma nominal, isso diminui o índice de não concordância. É o caso, por exemplo, em (6):

(5) Os peixe pula

(6) Os peixes pulam

${ }^{6}$ Os exemplos relacionados à pesquisa de Vieira (1995) foram extraídos de Vieira (2011). 
Vieira (2011) observou, no entanto, que sujeitos constituídos por numerais que dão ideia de plural desfavorecem a concordância de forma significativa. É o caso mostrado em (7), por exemplo. Para a autora, esse fato permite que se conclua que o princípio do paralelismo atua pela repetição de formas, e não pela repetição de ideias. No nível discursivo, Vieira (2011) observou que, quando se trata de verbos em série, a realização da forma plural verbal leva à realização de novas formas verbais no plural no contexto seguinte, $\mathrm{e}$ vice-versa. Como exemplo, temos a sentença em (8).

(7) Os dois pula

(8) Os peixes pula $\varnothing$, sai $\varnothing$ e corre $\varnothing$

Em (8), o referente do sujeito dos verbos é o mesmo, mas, segundo a autora, o fato de o elemento sujeito dos verbos ter a mesma referência ou ter referências distintas não se mostra relevante.

Em relaçãoà posposição do sujeito ao verbo, verificou-se que esse é um contexto que desfavorece acentuadamente a concordância, tal como se mostra em (9).

(9) Chegou os livros

Nos casos em que o sujeito se antepõe ao verbo, predomina a concordância; no entanto, quando ocorrem sintagmas nominais retomados pelo pronome relativo "que", que não é uma forma marcada quanto ao número, a concordância é desfavorecida.

A animacidade do sujeito e a distância entre o núcleo do SN sujeito e o verbo, segundo Vieira, "apresentam comportamento instável em relação à concordância verbal e demonstram exercer influência de nível secundário" (VIEIRA, 2011, p. 91), De acordo com a autora, sujeitos inanimados desfavorecem a concordância, 
quando comparados aos sujeitos animados; além disso, quanto maior é a distância entre o sujeito e o verbo, menor é a tendência à concordância.

Por fim, Vieira destaca que, embora sejam os fatores linguísticos os que mais desfavorecem a concordância verbal, um fator extralinguístico também se mostrou relevante nesse sentido: a idade do falante. Quanto mais velho o falante, maior a ausência de concordância. A autora argumenta que os menores índices de cancelamento na fala dos indivíduos mais jovens decorrem de um complexo de fatores que abrange todas as injunções sociocomportamentais que envolvem esses indivíduos, tais como o contato com o turismo e o acesso a meios culturais (VIEIRA, 2011, p. 91).

Berlincketal.(2009) também analisaram dados de fala de falantes cultos e observaram os contextos em que a concordância verbal se manifesta de forma sistemática e quando é variável. Segundo as autoras, no PB os falantes cultos tendem a mostrar marcas explícitas de concordância verbal na presença de sujeitos nominais (cf. (10)), de sujeitos pronominais plenos e de sujeitos pronominais nulos (cf. (11)) ${ }^{7}$

(10) os veteranos ofereciam um piquenique aos... calouros então nós fomos até Itaparica.

(11) Eu levei as minhas filhas ${ }_{\mathrm{i} .}$ Elas $_{\mathrm{i}}$ adoraram, né? $[\varnothing]_{\mathrm{i}}$ não queriam ir, mas no fim $[\varnothing]_{\mathrm{i}}$ foram, porque $[\varnothing]_{\mathrm{i}}$ sabiam que iam outros jovens também.

Segundo Berlinck, falantes cultos exibem, ainda, marcas de concordância que a prescrição gramatical rejeita (cf. (12)), assim como ausência de concordância nas orações adjetivas (cf. (13)) e concordância variável com sujeito coletivo (cf. (14)).

(12) Não podíamos deixar de falarmos novamente no externo.

${ }^{7}$ Os exemplos de (10) a (18) foram extraídos de Berlinck et al. (2009). 
(13) O importante é que o professor proponha diferentes atividades que envolva diferentes processos mentais.

a. A molecada adorou o filme.

b. O pessoal gozou com aquela turma ${ }_{i}$, que ${ }_{i}$ levaram o dia inteiro para arrumar a canoa.

Nas orações com verbo inacusativo, segundo Berlinck et al. (2009), falantes cultos optam pela ordem verbo-sujeito (VS), especialmente com verbos existenciais, tais como existir e aparecer (cf. (13)), mas mostram que a concordância com o sujeito pós-verbal não lhes é natural (cf. (14)); em construções passivas, predominam as formas que não exibem marcas de concordância (cf. (15)).

(15) Então existe uma época pra ter maçã.

(16) Então aí mudou mudaram-se os hábitos.

(17)
a. Não se usava botinhas.
b. Aquelas carroças vinham cheias de defuntos para serem enterrado.

Ainda segundo Berlinck et al. (2009), além das construções com verbos inacusativos, outro contexto que licencia a ordem VS para os verbos transitivos e inergativos é o que envolve um sintagma nominal pesado (ou simplesmente SN pesado), que as autoras definem como "um sintagma longo, com modificadores e complementos do nome, que podem ser representados por sintagmas simples ou sentenciais" (BERLINCK et al., 2009, p. 112). Não havendo SNs pesados, ocorre categoricamente a ordem sujeito-verbo (SV). Exemplos de sentenças com SN pesado estão ilustrados em (18): 
a. Isso foi o que decidiram os deputados da bancada ruralista recém-chegados.

b. Só dormiram os meninos que chegaram do passeio ao Parque Ecológico.

Outro estudo sobre a manifestação da concordância verbal na fala culta é o supramencionado trabalho de Graciosa (1991). Graciosa (1991 apud VAREJÃO 2006) analisa a fala de indivíduos escolarizados da cidade do Rio de Janeiro a partir de dados do Projeto NURC.

Graciosa (1991) verificou um índice de concordância verbal bastante alto nos dados analisados. Constatou, ainda, fatores que favorecem e fatores que desfavorecem a concordância. Como fatores favorecedores, a autora apontou os seguintes ${ }^{8:}$

a. anteposição do sujeito a um verbo transitivo:

Eles [os sindicatos] ganham (...). Embora associações sindicais fossem sendo surgidas em tempos vários.

b. proximidade do SN sujeito ao verbo:

Os portugueses conhecem como sopa de entulho.

c. sequência discursiva em que se encontra o verbo:

As moças arranjam os problemas delas lá fora e voltam pra casa pra mamãe criar o que elas arranjaram (...)

Como fatores desfavoráveis, Graciosa (1991 apud VAREJÃO 2006) indicou os três mais fortes:

(20)

a. posposição do SN sujeito ao verbo:

(...) Não, o banco daqui, a agência, mas lá, deveria eles alertar a pessoa que foi (...)

\footnotetext{
${ }^{8}$ Os exemplos (19) e (20), de contextos que favorecem e que desfavorecem a concordância, foram extraídos de Varejão (2006).
} 
b. distância entre o sujeito e o verbo:

A criança desde pequenininha, dois anos, três anos, já se criam (...).

c. ocorrência de sujeito com verbo isolado na cadeia discursiva:

Isso é que foi a meninice da gente, através de livros, através de professores, através do dia-a-dia de casa, de pai e mãe, aquelas conversas assim de, de tios, de parentes então que vinha

A conclusão do trabalho de Graciosa (1991 apud VAREJÃO 2006) é que, na fala culta, a concordância verbal é um fenômeno extremamente controlado por fatores linguísticos e sociais ${ }^{9}$. Varejão acrescenta que, nesse sentido, a concordância verbal é governada por regras variáveis tanto na fala culta quanto na fala não culta.

As variáveis linguísticas e sociais consideradas nos trabalhos apresentados nesta seção foram fundamentais para a seleção das variáveis consideradas na presente pesquisa. Os contextos apresentados no estudo de Berlinck et al. 2009 determinaram, inicialmente, os contextos analisados em Zandomênico (2018), no que diz respeitoàsvariantes linguísticas concernentesàconcordância verbal. Posteriormente, a autora retomou os dados incorporando algumas das variáveis linguísticas consideradas nos estudos sociolinguísticos também apresentados nesta seção (SCHERRE \& NARO 1998; VIEIRA 2011; GRACIOSA 1991; BERLINCK et al., 2009), tais como a saliência fônica, a posição do sujeito em relação ao verbo e a animacidade do sujeito. Retomaremos essa questão na seção 1.2.

\footnotetext{
${ }^{9}$ Sobre os fatores sociais analisados por Graciosa (1991), Varejão (2006) menciona que a autora selecionou gênero, faixa etária ( 25 a $35 ; 36$ a 55 ; mais de 56 anos) e zona geográfica de residência na cidade do Rio de Janeiro (norte, sul e suburbana), mas não explicita os resultados específicos da análise dessas variáveis sociais. O trabalho de Graciosa (1991), que consiste em uma dissertação de mestrado, foi realizado em momento anterior ao advento da Internet e não foi publicado posteriormente. Sendo assim, dadas as dificuldades de acesso ao texto original, acessamos a resenha presente no texto de Varejão (2006).
} 
Vejamos, agora, o que dizem os estudos sobre a concordância verbal na escrita.

\subsubsection{Estudos variacionistas sobre a concordância verbal na escrita}

Mesmo no âmbito da Sociolinguística, há mais pesquisas desenvolvidas com dados de fala do que com dados de escrita. Nessa área, alguns estudos realizados por Scherre (2005) e por Scherre \& Naro (2007) sobre a concordância verbal na escrita são particularmente relevantes para a presente análise, além do já mencionado artigo sobre a concordância de número no português falado no Brasil, em que Scherre \& Naro (1998) (conforme já mencionamos na subseção anterior) tecem algumas observações a respeito da variação na escrita, em particular na escrita padrão.

Segundo Scherre \& Naro (1998), a variação registrada na escrita não se restringe aos casos elencados nas gramáticas brasileiras: ela ocorre em quatro grandes configurações estruturais:

(21)

a. Construções com sujeitos pospostos, independentemente de serem compostos

- SAIRÁ das AD's caravanas de docentes para participarem deste evento

b. Construções com sujeito simples de estrutura complexa, independentemente de expressarem noções quantitativas, coletivas ou partitivas.

- A programação das grandes emissoras REFLETE sua linha de pensamento.

- Um grupo de turistas CHEGAM a uma aldeia de canibais e vão a um restaurante.

c. Construções com sujeito que expressam percentual.

- 70\% ACHAM que o presidente conseguirá encontrar ...

- 59\% ACHA que o governo é a favor dos ricos. 
(22) Construções com sujeito composto singular de estrutura complexa.

- O crescimento e o dinamismo da economia da Tailândia SÃO incompatíveis com a tradição de compra de votos.

Segundo os autores, em casos de sujeito de um só núcleo de estrutura complexa, por exemplo, como em (21b), o controle da concordância também pode ser determinado pelo núcleo do sintagma nominal (no exemplo, "emissoras" e "turistas") dentro do sintagma preposicional adjunto ou complemento. (cf. SCHERRE 1995; SCHERRE \& NARO 1995; apud SCHERRE \& NARO 1998).

Sobre a variação da concordância de número, Scherre (2005) afirma que ela está instalada no PB falado. No entanto, há indícios de variação também na língua escrita, ainda que em grau bastante baixo. Isso inclui, segundo a autora, "a escrita de pessoas escolarizadas submetida a um mínimo de revisão, ou seja, na escrita com algum grau de monitoração" (SCHERRE 2005, p. 20). A autora afirma não haver dúvidas de que a variação da concordância de número na escrita apresenta frequência pouco perceptível ao leitor não envolvido na análise objetiva de dados linguísticos, especialmente na escrita monitorada (op. cit::20-21).

Scherre (2005) retoma os contextos que envolvem a variação na escrita (cf. SCHERRE \& NARO 1998) e reafirma a tese de que a escrita culta espelha regularidades inerentes à variação da fala culta. A autora acrescenta mais dados que confirmam essa tese, como se pode verificar nos exemplos abaixo: ${ }^{10}$

(23) construções com sujeito (composto ou não) à direita do verbo:

- Nãoimporta as sucessivas decisões judiciaisfavoráveis, ao pagamento. (Correio Braziliense, 28/11/2001, p.3, c.3)

${ }^{10}$ Exemplos de (23) a (26) extraídos de Scherre (2005). 
(24) construções com sujeito simples de estrutura complexa:

- Lembramos que a estipulação dos prazos acima decorrem da necessidade de melhor aproveitamento dos recursos disponíveis para o exercício de 1994 (Oficio Circular no. 6o MEC/SESU, 17/03/1994)

(25) construções com sujeitos que expressam percentual:

- ...dois terços dos analfabetos do mundo são mulheres (Folha de São, 16/04/1995, Mais!, p.5-3, c.1)

(26) construções com sujeito composto singular de estrutura complexa:

- A adoção do real e o seu impacto na economia nacional (...) divide as opiniões na cidade (Jornal do Brasil, 29/05/1994, p. 25, c.3)

\subsection{A concordância verbal na escrita (ZANDOMÊNICO 2018)}

Em Zandomênico $(2018)^{11}$, analisou-se, relativamente à concordância verbal, em dados de escrita da EJA e de alunos do ensino regular, a influência de alguns grupos de fatores já analisados em dados de fala. São eles:

a) fatores linguísticos:

- saliência fônica,

- tipo verbal,

- animacidade do sujeito,

- posição do sujeito,

- complexidade do sujeito;

\footnotetext{
${ }^{11}$ Em Zandomênico (2018), foram analisadas, ao todo, 240 redações do ENEM 2013: 120 redações de alunos provenientes da EJA e 120 redações de alunos provenientes do ensino regular. Nessas redações, foram coletados 1.336 dados de concordância verbal.
} 
b) fatores sociais:

- sexo,

- idade.

Com relação à saliência fônica, observou-se que, em ambas as amostras (EJA e ensino regular), o número de marcas de concordância explícita nos casos de maior saliência fônica $(83,2 \%$ na EJA e $88,0 \%$ no ensino regular) foi mais alto que nos casos de menor saliência fônica (76,9\% na EJA e 85,3\% no ensino regular). Portanto, ambas as amostras confirmaram o que estudos anteriores (NARO 1981; SCHERRE \& NARO 1998; VIEIRA 2011) já haviam constatado a respeito da saliência fônica na fala: quanto maior é a distinção fônica entre as formas singular e plural, maiores são as chances de haver concordância. ${ }^{12}$

Com relação ao tipo verbal, constatou-se que, no caso da EJA, os contextos de verbos não transitivos e não inacusativos foram os que apresentaram mais concordância explícita (83,8\%), seguidos dos contextos de verbos transitivos $(80,4 \%)$. Já no caso do ensino regular, foram os contextos de verbos transitivos $(88,5 \%)$ os que mais apresentaram marcas de concordância, seguidos imediatamente pelos contextos de outros tipos verbais (83,7\%). Em qualquer das modalidades de ensino, no entanto, observou-seque os dois contextos que apresentaram mais concordância exibiram mais de $80 \%$ de frequência de marcas. Os contextos de verbos inacusativos, tanto na EJA quanto no ensino regular, foram os que exibiram menos marcas de concordância ( $61,2 \%$ e 76,6\%, respectivamente), e a uma distância razoável do tipo verbal que ocupava a segunda posição $(80,4 \%$ e $83,7 \%$, respectivamente) ${ }^{13}$. Quanto ao verbo transitivo, Graciosa

${ }^{12}$ Uma questão interessante a ser destacada é o fato atestado pelo estudo variacionista presente em Zandomênico (2018) de que, assim como a fala, a escrita também apresenta, entre as suas variáveis, a saliência fônica.

${ }^{13}$ No estudo de Zandomênico (2018), o qual serviu de base para o presente artigo, foram 
(1991) constatou que esse tipo verbal ocorre mais em contextos de ordem SV do que de ordem VS, portanto os contextos de que o verbo transitivo participa exibem mais marcas de concordância verbal. Quanto ao verbo inacusativo, Berlinck et al. (2009) verificaram o oposto: esse tipo verbal ocorre mais em contextos de ordem VS do que de ordem SV, portanto os contextos de que o verbo inacusativo participa exibem menos marcas de concordância verbal. Esses fatos foram confirmados por Zandomênico (2018) na amostra da EJA e também na amostra do ensino regular.

Quanto à animacidade do sujeito, tanto na amostra da EJA quanto na do ensino regular, o número de marcas de concordância explícita nos casos de sujeito [+ animado] superou o número de marcas nos casos de sujeito [- animado]. Portanto, as amostras confirmaram o que estudos anteriores também já haviam constatado a respeito da animacidade do sujeito: sujeitos animados favorecem a presença de marcas de concordância.

Quanto à posição do sujeito, novamente os resultados, em ambas as amostras analisadas em Zandomênico (2018), confirmaram o que estudos já atestavam quanto à posição do sujeito antecedente quanto mais próximo ele está do verbo, maiores as chances de marcas de concordância - e quanto ao sujeito posposto - sujeitos à direita do verbo desfavorecem robustamente a concordância.

A análise dos dados escritos da EJA e do ensino regular não confirmou os estudos anteriores apenas com relação aos contextos de sujeitos retomados por "que" (isto é, em orações adjetivas). Segundo estudos anteriores (VIEIRA 2011; GRACIOSA 1991; BERLINCK et al.) apontavam, sujeitos retomados por "que" desfavorecem a concordância verbal na fala. Em Zandomênico (2018), no entanto, constatou-se que, na escrita, os contextos de sujeito retomado por

encontrados, ao todo (ou seja, nos dados de ensino regular e da EJA), 54 dados de ordem VS, dos quais 34 (63\%) apresentavam verbo inacusativo. Dos 67 contextos de verbos inacusativos encontrados nas redações, 34 (50,75\%) apresentavam ordem VS. 
"que" exibiram altas taxas de concordância (frequência média de $86 \%)$.

Com relação ao paralelismo discursivo, constatou-se que, como estudos prévios (VIEIRA 2011; GRACIOSA 1991) já atestavam, nesse tipo de contexto, a realização da forma plural no verbo favorece a realização de novas formas verbais no plural no contexto seguinte. Na mostra da EJA, contextos de paralelismo discursivo apresentaram $81,8 \%$ de marcas de concordância; na amostra do ensino regular, foram $89,4 \%$.

Quanto à complexidade do sujeito, nas duas amostras, observouse que o número de marcas de concordância explícita nos casos de sujeito complexo (72,3\% na EJA e $81,81 \%$ no ensino regular) foi menor do que praticamente todos os outros contextos linguísticos analisados ${ }^{14}$, apresentando frequência maior de marcas somente do que o apresentado nos contextos considerados bastante desfavorecedores de concordância (verbo inacusativo, sujeito posposto e estruturas sem paralelismo discursivo). Logo, na escrita, assim como na fala (cf. SCHERRE \& NARO 1998; SCHERRE 2005), Zandomênico (2018) constatou que, em casos de sujeitos (simples ou compostos) de estrutura complexa, ocorre variação.

Quanto à faixa etária, verificou-se que a maior concentração de marcas de concordância estava nos dados escritos por falantes de até 29 anos (82,6\%). Nos dados de falantes com 30 anos ou mais, a taxa de concordância apresentou sensível queda (69,5\%). No caso dos dados do ensino regular, a maioria absoluta dos dados foi produzida por falantes mais novos, que apresentaram uma taxa de concordância de $86,3 \%$. Do total de 799 dados de redações do ensino regular, 795 foram produzidos por falantes de até 19 anos e apenas 4 foram produzidos

\footnotetext{
${ }^{14}$ Eles são onze, ao todo: a) verbo [+ saliente], b) verbo [- saliente], c) verbo transitivo, d) verbo não transitivo e não inacusativo, e) sujeito [+ humano], f) sujeito [- humano], g) sujeito imediatamente antes do verbo, h) sujeito anteposto menos distante do verbo, i) sujeito anteposto mais distante do verbo, $\mathrm{j}$ ) sujeito complexo e $\mathrm{k}$ ) contextos com paralelismo discursivo.
} 
por falantes com idade entre 20 e 29 anos. Vieira (2011), com relação à amostra de fala de analfabetos, constatou que, quanto mais velho o falante, menores as chances de marcas de concordância. Olhando exclusivamente para a idade dos falantes, as amostras da EJA e do ensino regular analisadas em Zandomênico (2018) confirmam essa constatação.

Já Scherre \& Naro (1998) constataram que pessoas mais pressionadas socialmente por estarem em idade profissionalmente produtiva empregam mais marcas de concordância. Nas amostras analisadas por Zandomênico (2018), havia, ao todo, 161 falantes de até 19 anos (44 da EJAe 117 do ensino regular) e 79 falantes com 20 anos ou mais (dos quais apenas 3 eram do ensino regular). Se consideramos, grosso modo, que, em ambas as amostras, somente os falantes com 20 anos ou mais estariam em idade profissionalmente produtiva e que esses falantes exibiram uma média de $75,68 \%$ de marcas de concordância, enquanto os falantes com até 19 anos exibiram 85,46\% de concordância, então o que Scherre \& Naro (1998) observaram na fala não se confirmou na amostra escrita analisada por Zandomênico (2018).

Quanto ao sexo, o que os estudos (como o de SCHERRE \& NARO, 1998) indicam é que pessoas do sexo feminino empregam mais marcas de concordância do que falantes do sexo masculino. No entanto, nas amostras de EJA e do ensino regular, o que foi observado é que, nos dados produzidos por homens, havia $81,8 \%$ de frequência de marcas de concordância, enquanto, nos dados produzidos por mulheres, havia $76,7 \%$. O que se constatou na fala, portanto, não se confirmou na análise de Zandomênico (2018) relativamente à escrita. Vale observar que, nesta análise, o número de dados

A análise constatou que, independentemente do nível de escolaridade do falante e independentemente da modalidade em que se usa a língua (escrita ou falada), as variáveis que estão em jogo na concordância verbal são muito semelhantes. 
Vejamos, no quadro abaixo, um resumo das principais constatações dos estudos variacionistas analisados e de Zandomênico (2018), no que diz respeito às variáveis linguísticas e sociais que estão em jogo na concordância verbal.

\section{(27) A influência das variáveis linguísticas e sociais relevantes para a concordância verbal na fala e na escrita, segundo Naro (1981), Scherre \& Naro (1998), Vieira (2011), Graciosa (1991), Berlinck et al. (2009) e Zandomênico (2018)}

\begin{tabular}{|c|c|c|c|c|c|c|}
\hline $\begin{array}{l}\text { AUTORES } \\
\text { (escolarida- } \\
\text { de dos } \\
\text { falantes } \\
\text { analisados/ } \\
\text { tipo de dados } \\
\text { analisados) } \\
\quad \text { J } \\
\text { VARIÁVEL } \\
\quad \text { K }\end{array}$ & $\begin{array}{l}\text { NARO } 1981 \\
\text { (analfabetos } \\
\text { /fala) }\end{array}$ & $\begin{array}{l}\text { SCHERRE \& } \\
\text { NARO } 1998 \\
\text { (falantes com } \\
\text { escolaridade } \\
\text { entre } 1 \text { e } 11 \text { anos } \\
\text { /fala e escrita) }\end{array}$ & $\begin{array}{l}\text { VIEIRA } 2011 \\
\text { (analfabetos e } \\
\text { semianalfa- } \\
\text { betos/fala) }\end{array}$ & $\begin{array}{l}\text { GRACIOSA } \\
1991 \\
\text { (falantes } \\
\text { cultos/fala) }\end{array}$ & $\begin{array}{l}\text { BERLINCK ET } \\
\text { AL. } 2009 \\
\text { (falantes } \\
\text { cultos/fala) }\end{array}$ & $\begin{array}{l}\text { ZANDOMÊNICO } \\
2018 \\
\text { (concluintes de } \\
\text { Ensino Médio-EJA } \\
\text { e ensino regular / } \\
\text { escrita) }\end{array}$ \\
\hline $\begin{array}{l}\text { Saliência } \\
\text { fônica }\end{array}$ & $\begin{array}{l}\text { Quanto maior a } \\
\text { diferença fônica } \\
\text { entre as formas } \\
\text { singular e } \\
\text { plural, maiores } \\
\text { as chances de } \\
\text { concordância }\end{array}$ & $\begin{array}{l}\text { Quanto maior } \\
\text { a diferença } \\
\text { fônica entre } \\
\text { as formas } \\
\text { singular e } \\
\text { plural, maiores } \\
\text { as chances de } \\
\text { concordância }\end{array}$ & $\begin{array}{l}\text { Quanto maior } \\
\text { a diferença } \\
\text { fônica entre } \\
\text { as formas } \\
\text { singular e } \\
\text { plural, maiores } \\
\text { as chances de } \\
\text { concordância }\end{array}$ & - & - & $\begin{array}{l}\text { Há mais marcas } \\
\text { de concordância } \\
\text { explícita quando a } \\
\text { saliência fônica é } \\
\text { maior }\end{array}$ \\
\hline $\begin{array}{c}\text { Posição do } \\
\text { sujeito }\end{array}$ & $\begin{array}{c}\text { Sujeitos } \\
\text { imediatamente } \\
\text { antepostos } \\
\text { ao verbo } \\
\text { favorecem a } \\
\text { concordância; } \\
\text { sujeitos } \\
\text { separados } \\
\text { do verbo por } \\
\text { elementos } \\
\text { intervenientes, } \\
\text { assim como } \\
\text { sujeitos } \\
\text { pospostos, } \\
\text { desfavorecem a } \\
\text { concordância }\end{array}$ & $\begin{array}{c}\text { Sujeitos } \\
\text { imediatamente } \\
\text { antepostos } \\
\text { ao verbo } \\
\text { favorecem a } \\
\text { concordância; } \\
\text { sujeitos } \\
\text { separados } \\
\text { do verbo por } \\
\text { elementos } \\
\text { intervenientes, } \\
\text { assim como } \\
\text { sujeitos } \\
\text { pospostos, } \\
\text { desfavorecem a } \\
\text { concordância }\end{array}$ & $\begin{array}{c}\text { Sujeitos } \\
\text { imediatamente } \\
\text { antepostos } \\
\text { ao verbo } \\
\text { favorecem a } \\
\text { concordância; } \\
\text { sujeitos } \\
\text { separados } \\
\text { do verbo por } \\
\text { elementos } \\
\text { intervenientes, } \\
\text { assim como } \\
\text { sujeitos } \\
\text { pospostos, } \\
\text { desfavorecem a } \\
\text { concordância }\end{array}$ & $\begin{array}{c}\text { Sujeitos } \\
\text { imediatamente } \\
\text { antepostos } \\
\text { ao verbo } \\
\text { favorecem a } \\
\text { concordância; } \\
\text { sujeitos } \\
\text { separados } \\
\text { do verbo por } \\
\text { elementos } \\
\text { intervenientes, } \\
\text { assim como } \\
\text { sujeitos } \\
\text { pospostos, } \\
\text { desfavorecem a } \\
\text { concordância }\end{array}$ & $\begin{array}{c}\text { Sujeitos } \\
\text { pospostos } \\
\text { aoverbo } \\
\text { desfavorecem } \\
\text { a concordância }\end{array}$ & $\begin{array}{c}\text { Em caso de sujeito } \\
\text { antecedente, } \\
\text { quanto mais } \\
\text { próximo ele está } \\
\text { do verbo, maiores } \\
\text { as chances de } \\
\text { concordância. } \\
\text { Sujeitos pospostos } \\
\text { desfavorecem } \\
\text { robustamente a } \\
\text { concordância }\end{array}$ \\
\hline $\begin{array}{l}\text { Paralelismo } \\
\text { no nível } \\
\text { discursivo } \\
\text { (verbos em } \\
\text { série) }\end{array}$ & - & - & $\begin{array}{l}\text { A realização da } \\
\text { forma plural } \\
\text { verbal favorece } \\
\text { a realização } \\
\text { de novas } \\
\text { formas verbais } \\
\text { no plural no } \\
\text { contexto } \\
\text { seguinte }\end{array}$ & $\begin{array}{l}\text { A realização da } \\
\text { forma plural } \\
\text { verbal favorece } \\
\text { a realização } \\
\text { de novas } \\
\text { formas verbais } \\
\text { no plural no } \\
\text { contexto } \\
\text { seguinte }\end{array}$ & - & $\begin{array}{l}\text { A realização da } \\
\text { forma plural no } \\
\text { verbo favorece a } \\
\text { realização de novas } \\
\text { formas plurais no } \\
\text { contexto seguinte }\end{array}$ \\
\hline
\end{tabular}




\begin{tabular}{|c|c|c|c|c|c|c|}
\hline $\begin{array}{l}\text { SN retomado } \\
\text { por "que" }\end{array}$ & - & - & $\begin{array}{l}\text { SNs retomados } \\
\text { por "que" } \\
\text { desfavorecem a } \\
\text { concordância }\end{array}$ & $\begin{array}{l}\text { SNs retomados } \\
\text { por "que" } \\
\text { desfavorecem a } \\
\text { concordância }\end{array}$ & $\begin{array}{l}\text { SNs retomados } \\
\text { por "que" } \\
\text { desfavorecem } \\
\text { a concordância }\end{array}$ & $\begin{array}{l}\text { Contextos de } \\
\text { sujeitos retomados } \\
\text { por "que" exibiram } \\
\text { altas taxas de } \\
\text { concordância } \\
\text { (média de } 86 \% \text { ) }\end{array}$ \\
\hline $\begin{array}{c}\text { Animacidade } \\
\text { do sujeito }\end{array}$ & - & - & $\begin{array}{c}\text { Sujeitos } \\
\text { inanimados } \\
\text { desfavorecem a } \\
\text { concordância }\end{array}$ & - & - & $\begin{array}{l}\text { Sujeitos animados } \\
\text { favorecem a } \\
\text { presença de marcas } \\
\text { de concordância }\end{array}$ \\
\hline $\begin{array}{l}\text { Verbo } \\
\text { transitivo }\end{array}$ & - & - & - & $\begin{array}{l}\text { A anteposição } \\
\text { do sujeito } \\
\text { a um verbo } \\
\text { transitivo } \\
\text { favorece a } \\
\text { concordância }\end{array}$ & - & $\begin{array}{l}\text { Verbos transitivos } \\
\text { ocorrem com mais } \\
\text { frequência em } \\
\text { contextos de ordem } \\
\text { SV e favorecem a } \\
\text { concordância }\end{array}$ \\
\hline $\begin{array}{c}\text { Verbo } \\
\text { inacusativo }\end{array}$ & - & - & - & - & $\begin{array}{c}\text { Ocorre } \\
\text { com mais } \\
\text { frequência } \\
\text { em contextos } \\
\text { de ordem } \\
\text { VS - portanto, } \\
\text { com menos } \\
\text { marcas de } \\
\text { concordância }\end{array}$ & $\begin{array}{l}\text { Verbos inacusativos } \\
\text { ocorrem com mais } \\
\text { frequência em } \\
\text { contextos de ordem } \\
\text { VS e desfavorecem a } \\
\text { concordância }\end{array}$ \\
\hline SN complexo & & $\begin{array}{c}\text { Há variação } \\
\text { nas marcas de } \\
\text { concordância. }\end{array}$ & & & & $\begin{array}{l}\text { Há variação } \\
\text { nas marcas de } \\
\text { concordância* }\end{array}$ \\
\hline Idade & $\begin{array}{l}\text { Aparentemente } \\
\text { indiferente }\end{array}$ & $\begin{array}{c}\text { Pessoas mais } \\
\text { pressionadas } \\
\text { pela } \\
\text { idade } \\
\text { profissional- } \\
\text { mente } \\
\text { produtiva } \\
\text { empregam } \\
\text { mais marcas de } \\
\text { concordância }\end{array}$ & $\begin{array}{l}\text { Quanto mais } \\
\text { velho o falante, } \\
\text { menores as } \\
\text { chances de } \\
\text { concordância }\end{array}$ & - & - & $\begin{array}{c}\text { Quanto mais } \\
\text { velhos os falantes, } \\
\text { menores as chances } \\
\text { de concordância. } \\
\text { Pessoas em idade } \\
\text { profissionalmente } \\
\text { produtiva (20 anos } \\
\text { ou mais) exibiram } \\
\text { menos marcas de } \\
\text { concordância do } \\
\text { que falantes mais } \\
\text { novos (com até } 19 \\
\text { anos) }\end{array}$ \\
\hline Sexo & $\begin{array}{l}\text { Aparentemente } \\
\text { indiferente }\end{array}$ & $\begin{array}{l}\text { Pessoas do } \\
\text { sexo feminino } \\
\text { empregam } \\
\text { mais as } \\
\text { marcas de } \\
\text { concordância }\end{array}$ & - & - & - & $\begin{array}{c}\text { Pessoas do } \\
\text { sexo masculino } \\
\text { apresentaram } \\
\text { mais marcas de } \\
\text { concordância do } \\
\text { que pessoas do sexo } \\
\text { feminino }\end{array}$ \\
\hline
\end{tabular}

* Consideramos que há variação ainda que tenham sido encontrados mais dados com marcas explícitas de concordância do que sem marcas. A frequência de concordância apresentada em contextos de SN complexo (72,3\% na EJA e 81,81\% no ensino regular) foi menor do que em contextos de SN não complexo (79,8\% na EJA e $87,4 \%$ no ensino regular). (ZANDOMÊNICO, 2018, p. 159) 
O quadro acima sintetiza as ideias apresentadas nessa seção. Nele, podemos observar que o único contexto linguístico em que a influência da variável é distinta na fala e na escrita é o de sujeito retomado por "que". Nos demais contextos, a influência das variáveis analisadas para a concordância verbal é muito semelhante.

\section{Considerações sobre a gramática da escrita}

Apresentaremos, em 2.1 e 2.2, as duas abordagens de aquisição de uma segunda gramática mencionadas na introdução deste trabalho: Roeper (1999) e Kato (2005), respectivamente. Em seguida, em 2.3, faremos uma análise quanto ao estatuto da gramática do letrado no que se refere à concordância verbal

\subsection{A teoria do bilinguismo universal}

Segundo Roeper (1999, p. 7), os falantes têm um conjunto de minigramáticas para diferentes domínios, o que significa dizer que, de fato, todos os falantes são bilíngues. $\mathrm{O}$ autor argumenta que a checagem de tempo verbal e de concordância, entre outros, leva a representações bilíngues. Essa perspectiva sobre o bilinguismo teórico sugere que a opcionalidade (a variação) e os estágios na aquisição de uma gramática inicial também devem ser caracterizados como uma forma de bilinguismo.

De acordo com Roeper (1999, p. 3), em uma língua existem duas propriedades que não são "formuláveis" dentro de uma mesma gramática. A esse fenômeno o autor chama de Bilinguismo Teórico. $\mathrm{O}$ autor afirma que a noção social de bilinguismo, que consiste no domínio de duas línguas, por ser muito forte, pode dificultar a percepção de que pequenas variações gramaticais - que revelam a profundidade das propriedades da estrutura mental - também são formas de bilinguismo. 
Roeper (1999, p. 4) usa o conceito de Bilinguismo Teórico para captar aspectos da aquisição da linguagem (especificamente, a opcionalidade e a variação lexical). Ele inicia a discussão distinguindo língua e gramática nos termos de Chomsky (1986) - que faz uma distinção entre a língua internalizada, ou Língua-I (a gramática), e a língua externalizada, ou Língua-E (conjunto de enunciados que podem ser produzidos) - e argumenta que a língua externalizada, em última análise, pode não ser coerente, visto que pode apresentar escolhas "contraditórias".

Roeper (1999, p. 4-5) afirma que todas as línguas, quando vistas de perto, envolvem certos domínios que exibem essas escolhas contraditórias, de tal forma que ambas as opções de um parâmetro mutuamente exclusivo são escolhidas. Esse fato, segundo o autor, sugere que existe um bilinguismo oculto, e isso tem implicações para duas assunções correntes em pesquisas sobre aquisição.

A primeira assunção é a de que a criança passa por estágios de aquisição. Na perspectiva do Bilinguismo Teórico, uma criança aparentemente "entre estágios" está usando duas ou mais gramáticas (uma das quais irá desaparecer). Isso significa que uma criança pode usar, simultaneamente, traços gramaticais incompatíveis.

A segunda assunção é a de que certas regras são opcionais. De acordo com o Bilinguismo Teórico, a noção de opcionalidade pode ser eliminada, uma vez que, segundo Roeper (1999, p. 5), nenhuma gramática consistente pode apresentar regras contraditórias. Devese, nesse caso, postular que há duas gramáticas, ainda que elas difiram apenas em uma única regra.

A lógica da teoria da aprendizagem, para Roeper (1999, p.5), é que regras opcionais não podem ser eliminadas durante a aquisição, já que nenhum input positivo mostra que a regra opcional é incorreta. Em outras palavras, regras opcionais incorretas criam um superconjunto que deve ser restrito a um subconjunto, e não há mecanismo 
disponível para essa derivação ${ }^{15}$. Por outro lado, o movimento em sentido contrário, do subconjunto para o superconjunto, é claramente motivado pela evidência do input: se uma nova sentença não se conforma à gramática existente, isso força a gramática a ser revisada.

Roeper (1999, p. 5) afirma que a eliminação das regras opcionais pode ser um passo adiante em termos de aprendizado, mas que, por outrolado, novas questões surgem sobre a relação entre as gramáticas sob o pressuposto de que todos os falantes são bilíngues.

Uma extrapolação natural desse pressuposto é a afirmação de que uma pessoa tem inúmeras gramáticas, já que todas as classes lexicais com regras incompatíveis com as de outra classe devem constituir uma gramática separada. Para Roeper (1999, p. 6), embora pareça pesado e implausível argumentar que uma pessoa tem uma dúzia de gramáticas, a essência dessa afirmação pode ser verdadeira, e isso implica que a noção de gramática deve mudar para uma concepção mais local.

De acordo com Roeper (1999, p. 6), não há problemas no fato de que as "exceções" existam, pois elas podem ser todas vistas como "minigramáticas". Interessa, sim, como e por que as exceções são eliminadas em favor de uma extensa sistematicidade em gramática. Para o autor, onde duas gramáticas estão presentes, pode-se representar uma Minimal Default Grammar, definível em termos de economia.

\footnotetext{
${ }^{15}$ No original: "This is an important step from a formal perspective under what is known as Subset theory. The logic of learnability theory is this Optional rules cannot be eliminated by any straightforward mechanism in the process of acquisition, since no positive input shows that an optional rule is incorrect. In other words, incorrect optional rules create a superset which must be restricted to a subset. No mechanism is available for such a derivation. Movement from a subset to a superset, however, is clearly motivated by input evidence: a new sentence does not fit into the existing grammar, which forces the grammar to be revised. Elimination of optional rules is therefore, a step forward in learnability terms, but new questions arise about the relationship among grammars under the assumption that all speakers are bilingual."
} 
Em suma, o que Roeper (1999, p. 50) postula é que a Gramática Universal está disponível não só para a projeção de formas de L2 totalmente novas, mas também em um determinado idioma para criar ilhas radicalmente diferentes de variação de gramática.

\subsection{A gramática do letrado}

Kato (2005) traça um paralelo entre alguns pressupostos da Teoria Gerativa e os efeitos da Educação Básica na aquisição de uma gramática padrão, que é ensinada durante o período de escolarização, na escrita.

Segundo Kato (2005, p. 1), no Brasil, a gramática da fala e a "gramática" da escrita são tão distantes que a aquisição da escrita pela criança pode ter a natureza da aprendizagem de uma segunda língua. No que diz respeito ao possível acesso à Gramática Universal na aquisição da escrita, Kato $(2005$, p. 2) assume que existe acesso indireto, via a primeira gramática da língua - que, no caso do Português Brasileiro, corresponderia à gramática da língua falada (L1).

Para Kato, a gramática da Li contém uma periferia marcada na qual valores paramétricos opostos aos da gramática nuclear podem estar presentes, com caráter marcado, recessivo, e podem assumir um valor paramétrico durante a escolarização, em relação aos valores que se encontram definidos na gramática nuclear. Segundo Chomsky (1981), a periferia pode abrigar fenômenos de empréstimos, resíduos de mudança e invenções, de forma que indivíduos da mesma comunidade podem ou não apresentar esses fenômenos de forma marginal. Kato explora o conceito de "periferia" para dar conta da aprendizagem de uma segunda "gramática", a partir do input ordenado escolar ou da imersão em textos escritos. 
Para defender seu posicionamento, Kato (2005, p. 5-6) lista uma série de características comuns aos processos de aprender a escrever e de aprender uma segunda língua. Ela afirma que em ambos os processos: (i) há motivação social, e não determinação biológica; (ii) o início, em geral, ocorre após a idade crítica para a aquisição; (iii) o sucesso depende de dados positivos e de dados negativos; e (iv) há mais diferenças individuais. Afirma, ainda, que ambos os processos são vagarosos, não instantâneos, e que são essencialmente conscientes.

No que se refere à "aprendizagem" da escrita, Kato menciona evidências comportamentais, as quais chama de "erros de esquiva e hipercorreções" (KATO, 2005, p. 7), e defende que a morfossintaxe aprendida na escola tem estatuto estilístico, e não gramatical.

Kato, para a aprendizagem da escrita, defende a tese do acesso indiretoà GU. Ela se baseia em Hershensohn (apud KATO 2000, p. 7), que defende a mesma tese para a aquisição de L2. Para Hershensohn, as propriedades paramétricas relacionadas a um mesmo parâmetro não aparecem de forma simultânea na aquisição de L2. O surgimento do conjunto de propriedades de forma instantânea é característico da aquisição de L1, mas não da aquisição da L2. Segundo Hershensohn, esse fato não significa que os aprendizes de L2 não acessem a GU. Ela sugere a necessidade de maiores investimentos na pesquisa em aquisição de L2 para que a controvérsia sobre o surgimento de propriedades paramétricas se esclareça, uma vez que o surgimento de um conjunto de propriedades pela marcação de um parâmetro é uma idealização que não está postulada na Teoria Gerativa, no que diz respeito à L2.

Kato (2005, p. 5-8) afirma que, admitindo que a segunda gramática, seja a da L2 ou a da escrita, é restrita pelos Princípios e Parâmetros da GU, por meio do conhecimento da L1, ou da gramática da fala, resta-nos compreender como esta serve de base para esse novo conhecimento. Para a aquisição de uma "segunda gramática", 
Kato (2005, p. 9) defende que o falante letrado é um bilíngue desigual que tem, em sua língua internalizada (Língua-I), uma periferia marcada maior do que a dos não letrados. Nesse tipo particular de bilinguismo, há alternância de código (code-switching) entre a G1 da gramática nuclear e a G2 na periferia marcada. Para Kato (2005, p. 9), contudo, essa G2 não tem a mesma natureza da G1, sendo formada de fragmentos superficiais de uma gramática constituída pela fixação de parâmetros. Para esta autora, o que parece ocorrer, efetivamente, é que a "G2" constitui-se não por seleção paramétrica, mas por "regras estilísticas", selecionadas arbitrariamente de gramáticas passadas ou emprestadas da gramática portuguesa. Por fim, a autora afirma que as gramáticas nucleares "ficam restritas ao conhecimento accessível a qualquer ser humano, enquanto tudo o que nos diferencia se encontra nessa periferia que expande nossa Língua-I", e que a G2 é um subproduto da GU (KATO, 2005, p. 9).

\subsection{Estatuto da gramática do letrado no que se refere à concordância verbal}

A nosso ver, quando analisamos, sob uma perspectiva quantitativa, as variáveis que estão em jogo nos contextos de concordância verbal, tanto na fala quanto na escrita, constatamos que as duas modalidades de expressão se organizam segundo princípios bastante semelhantes. Por exemplo, tanto a escrita quanto a fala exibem, como fatores relevantes para a concordância verbal, a saliência fônica, o tipo de verbo, a ordem dos termos na oração e os traços de animacidade do sujeito. A exceção é o contexto em que sujeito é retomado pelo pronome "que", que, na escrita, favorece a presença de marcas de concordância, conforme Zandomênico (2018). ${ }^{16}$

${ }^{16}$ Deixamos para estudos futuros a análise e a explicação desse fenômeno. 
Dadas as semelhanças atestadas nos estudos variacionistas apresentados de forma resumida neste artigo, consideramos que, no que se refere à concordância verbal, a abordagem teórica que parece explicar melhor o processo de aquisição da escrita é a do bilinguismo universal. Vejamos por quê.

Sabe-se que a escrita e a fala constituem processos distintos. Enquanto a fala deriva de uma capacidade inata, a escrita é uma habilidade que deve ser aprendida - inicialmente, por meio do processo de alfabetização e, posteriormente, por meio dos processos de prática de escrita e letramento que fazem parte do processo escolar ao longo de toda a Educação Básica. A escrita, portanto, consiste em um processo complexo e não natural. A esse respeito, seguimos o pensamento de Lobato (2015, p. 25), que defende que ao texto e às atividades discursivas subjaz "a mesma gramática abstrata que subjaz às palavras, aos sintagmas, às orações e às frases”. Ainda segundo a autora:

Não pode ser diferente, pois, se assim o fosse, a mente humana estaria operando de modo antieconômico, com princípios de tipo diferente para domínios diferentes do mesmo objeto. O natural é considerar que, para o mesmo objeto, são usados os mesmos princípios abstratos. No texto, são usados princípios que extrapolam o limite da sentença. A diferença, a meu ver, está nas unidades com que a gramática opera num e noutro domínio, e não na natureza dos princípios.(LOBATO, 2015, p. 25)

$\mathrm{Na}$ análise dos dados escritos de indivíduos escolarizados das modalidades de ensino EJA e ensino regular, Zandomênico (2018) constatou que, no que diz respeito à concordância verbal, 
a) as variáveis que estão em jogo na escrita dos alunos da EJA e dos alunos do ensino regular são semelhantes às que estão em jogo na fala;

b) a escrita dos alunos da EJA e dos alunos do ensino regular constitui um sistema regular (e não um sistema que se constitui de fragmentos).

Pelas razões expostas acima, consideramos que a abordagem teórica que parece explicar melhor ao processo de aquisição da escrita, pelo menos no que diz respeito à concordância verbal, é a teoria do bilinguismo universal.

Como dito no início desta seção, os estudos sobre concordância verbal nos levaram a afirmar que é a hipótese do Bilinguismo Universal a que é capaz de explicar os dados da melhor forma. Seria interessante que outros estudos da mesma natureza fossem empreendidos relativamente a outros fenômenos da gramática do Português.

\section{Considerações finais}

Neste artigo investigamos os efeitos do processo de escolarização na constituição do conhecimento gramatical do falante letrado, por meio da análise variacionista dos padrões de concordância verbal. Comparamos os padrões de concordância verbal exibidos na fala e na escrita com o objetivo de verificar as variáveis em jogo em cada uma dessas modalidades e verificar a possibilidade de comparação entre as variáveis presentes em cada sistema, a fim de estabelecer correlações entre eles e de discutir a adequação das propostas de Roeper (1999) e Kato (2005) ao fenômeno estudado. Para tanto, estabelecemos comparações de base variacionista no que se refere aos padrões de concordância verbal usados em textos escritos por 
alunos oriundos da EJA e do ensino regular, recolhidos em provas do ENEM (ZANDOMÊNICO 2018), e a posterior comparação entre os resultados obtidos com os resultados de estudos variacionistas anteriores (NARO 1981; SCHERRE \& NARO 1998; VIEIRA 2011; GRACIOSA 1991; BERLINCK et al., 2009).

Os resultados da análise levaram à conclusão de que, em relação à concordância verbal, a hipótese mais adequada para dar conta do fenômeno estudado - a concordância verbal de indivíduos que passaram pela Educação Básica - foi a das gramáticas múltiplas, de Roeper (1999), em que se defende que todos os falantes possuem um conjunto de minigramáticas para serem usados em diferentes domínios. Isso porque os padrões de concordância verbal apresentados nos textos escritos analisados se mostraram sujeitos às mesmas variáveis da gramática da fala, com diferenças apenas em relação aos pesos das variáveis.

A hipótese da "gramática do letrado" de Kato (2005) foi considerada problemática no que se refere ao fenômeno da concordância verbal, pois, para a autora, a "gramática do letrado" é entendida como "constituída de fragmentos superficiais de uma gramática constituída pela fixação de parâmetros", do que discordamos, pelas razões expostas acima.

Ressaltamos a necessidade da elaboração de novos estudos e pesquisas sobre o tema para que possamos entender de que forma a gramática dos falantes letrados irá se manifestar relativamente a outros fenômenos linguísticos. 


\section{Referências}

BERLINCK, R. de A.; DUARTE, M. E. L. \& OLIVEIRA, M. de. Gramática do português culto falado no Brasil. Coord. geral: A. T. de CASTILHO; org.: KATO, M. A. \& NASCIMENTO, M. do. Campinas, SP: Editora da Unicamp, vol. 3 - A construção da sentença, cap. 3 - "Predicação". 2009.

BLEY-VROMAN, R. The logical problem of foreign language learning. In: Linguistic Analysis, 1990. vol. 20, number 1-2.

CHOMSKY, N. Aspects of the Theory of Syntax. Cambridge: MIT Press. 1965. Lectures on Government and Binding. Dordrecht: Foris. 1981. . Knowledge of Language - its nature, origin, and use. Nova York: Praeger. 1986.

Language and Problems of Knowledge: The Managua Lectures. The MIT Press. 1988.

HOUAISS, A. Dicionário Houaiss da língua portuguesa. Rio de Janeiro: Objetiva. 2009.

KATO, M. A gramática do letrado: questões para a teoria gramatical. In: MARQUES, M. A. et al. (orgs). Ciências da Linguagem: trinta anos de investigaçãoe e ensino. Braga, CEHUM (U. do Minho), 2005. p. 131-145.

KATO, M.; CYRINO, S. L. \& CORREAA, V. R. Brazilian Portuguese and the recovery of lost clitics through schooling. In: PIRES, A. \& ROTHMAN, J. (eds.) (2009). Minimalist Inquiries Into Child and Adult Language Acquisition: Case Studies across Portuguese. Berlim: Walter de Gruyter. 2009.

KENEDY, E. “O status da norma culta na língua-I dos brasileiros e seu respectivo tratamento na escola: algumas contribuições dos estudos formalistas à educação". In: GUESSER, S. (org.). Linguística, pesquisa e ensino. Boa Vista: Editora da UFRR, 2016, p. 173-196.

LABOV, W. Some Sociolinguistic Principles. In: C. B. PAULSTON \& G. R. TUCKER (Eds.) Sociolinguistics: The Essential Readings, Malden: Blackwell, 2003, 234-250. 
LEMLE, M. \& NARO, A. J. Relatório final de pesquisa apresentado às instituições patrocinadoras Fundação Movimento Brasileiro de Alfabetização (MOBRAL) e Fundação Ford. In: Competências básicas do português. Rio de Janeiro. Fundação Movimento Brasileiro de Alfabetização, 1977. p. 17-50.

LOBATO, L. [2003]. Linguística e ensino de línguas. Brasília: Editora UnB. 2015.

MOTA, M. A. Variant patterns of Subject-Verb agreement in Portuguese: morphological and phonological issues. In: Journal of Portuguese Linguistics, 2013. 12-2, 209-234.

MOTTA, M. F. da. O fenômeno variável da concordância verbal em redações da EJA. Dissertação de mestrado. Rio de Janeiro: UFRJ. 2011.

NARO, A. J. Dimensions of a syntactic change. Language, volume 57, number 1, 63-98.1981.

NARO, A. J. Linguística e Educação. In: BLANCHE, J. M. L. Problemas Sociolinguísticos de Iberoamérica. México: Instituto de Investigaciones Filológicas, Centro de Linguística Hispánica. 1984.

NARO, A. J. Modelos quantitativos e tratamento estatístico. In: MOLLICA, M. C. \& BRAGA, M. L. Introdução à Sociolinguística: o tratamento da variação. São Paulo: Contexto. 2007.

NARO, A. J. \& SCHERRE, M. M. P. Remodeling the age variable: Number concord in Brazilian Portuguese. Language Variation and Change, 25 (2013), 1-15. (c) Cambridge University Press. 2013.

PIRES, L. C. Aquisição da escrita-padrão do PB por brasileiros em esfera escolar. Tese de doutorado. Brasília: UnB. 2015.

ROEPER, T. Universal Bilingualism. Amherst: Univesity of Massachussets, Department of Linguistics. 1999. 
SANDOVAL, A. N. Concordância verbal com sujeitos complexos: uma operação sintática. In: PILATI, E. \& MOREIRA, B. (2018) Estudos formalistas das línguas naturais. Campinas, SP: Pontes Editores. 2018a.

O emprego de DPs encaixados licencia $(m)$ dupla concordância: concordância verbal com sujeitos complexos. Tese de doutorado. Brasília: UnB. $2018 \mathrm{~b}$.

SANDOVAL, A. N. \& ZANDOMÊNICO, S. C. M. R. "Concordância verbal em redações do ENEM produzidas por alunos da Educação de Jovens e Adultos EJA". Agália. Revista de Estudos na Cultura, vol. 114. Santiago de Compostela: AGAL. 2016.

SCHERRE, M. M. P. Doa-se lindos filhotes de poodle: variação linguística, mídia e preconceito. São Paulo: Parábola. 2005.

SCHERRE, M. M. P. \& NARO, A. J. Sobre a concordância de número no português falado do Brasil. In RUFFINO, G. (org.) Dialettologia, geolinguistica, sociolinguistica.(Atti del XXI Congresso Internazionale di Linguistica e Filologia Romanza) Centro di Studi Filologici e Linguistici Siciliani, Universitá di Palermo. Tübingen: Max Niemeyer Verlag, 5:509-523.1998.

Sociolinguistic correlates of negative evaluation: Variable concord in Rio de Janeiro. Language Variation and Change, 26 (2014), 331-357. (C) Cambridge University Press. 2014.

VANHOVE, J. The Critical Period Hypothesis in Second Language Acquisition: A Statistical Critique and a Reanalysis. In PLOS ONE. July 2013, vol. 8, Issue 7, e69172. 2013.

VAREJÃO, F. de O.A. Variação em estruturas de concordância verbal e em estratégias de relativização no português europeu popular. Tese de doutorado. Rio de Janeiro: UFRJ. 2006.

VIEIRA, S. R. Concordância verbal: variação em dialetos populares do Norte Fluminense. Dissertação de mestrado. Rio de Janeiro: UFRJ. 2005. . Concordância verbal. In: VIEIRA, S. R. \& BRANDÃO, S. Ensino de Gramática - Descrição e Uso. São Paulo: Contexto. 2011. 


\section{Como citar}

ZANDOMÊNICO, Stefânia; PILATI, Eloisa. Sobre concordância verbal, aprendizagem da escrita e gramáticas múltiplas. Revista da Abralin, v. 17, n. 1, p. 262-305, 2018.

Recebido 17/10/2018 e aceito em 24/01/2019. 